\title{
De ouderenzorg verdient beter
}

Citation for published version (APA):

Hamers, J. P. H. (2005). De ouderenzorg verdient beter: $(p<0.001)$. Maastricht University. https://doi.org/10.26481/spe.20051014jh

Document status and date:

Published: 14/10/2005

DOI:

10.26481/spe.20051014jh

Document Version:

Publisher's PDF, also known as Version of record

\section{Please check the document version of this publication:}

- A submitted manuscript is the version of the article upon submission and before peer-review. There can be important differences between the submitted version and the official published version of record.

People interested in the research are advised to contact the author for the final version of the publication, or visit the DOI to the publisher's website.

- The final author version and the galley proof are versions of the publication after peer review.

- The final published version features the final layout of the paper including the volume, issue and page numbers.

Link to publication

\footnotetext{
General rights rights.

- You may freely distribute the URL identifying the publication in the public portal. please follow below link for the End User Agreement:

www.umlib.nl/taverne-license

Take down policy

If you believe that this document breaches copyright please contact us at:

repository@maastrichtuniversity.nl

providing details and we will investigate your claim.
}

Copyright and moral rights for the publications made accessible in the public portal are retained by the authors and/or other copyright owners and it is a condition of accessing publications that users recognise and abide by the legal requirements associated with these

- Users may download and print one copy of any publication from the public portal for the purpose of private study or research.

- You may not further distribute the material or use it for any profit-making activity or commercial gain

If the publication is distributed under the terms of Article $25 \mathrm{fa}$ of the Dutch Copyright Act, indicated by the "Taverne" license above, 


\section{Oratie}

Universiteit Maastricht

\section{J.P.H. Hamers}

\section{De ouderenzorg verdient beter ( $p<0.001)$}

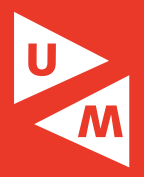


De ouderenzorg verdient beter ( $p<0.001)$ 


\section{Colofon}

Basisontwerp en realisatie: Océ Business Services, Universiteit Maastricht.

Voor mijn moeder

ISBN 90-5681-233-5

NUR 870

Alle rechten voorbehouden. Niets uit deze uitgave mag worden verveelvoudigd, opgeslagen in een geautomatiseerd gegevensbestand of openbaar gemaakt, zonder voorafgaande schriftelijke toestemming van de auteur of uitgever. 


\section{De ouderenzorg verdient beter $(p<0.001)$}

Inaugurale rede

Uitgesproken bij de aanvaarding van het ambt van bijzonder hoogleraar Verpleging en Verzorging van Ouderen aan de Universiteit Maastricht

op vrijdag 14 oktober 2005

door

Dr. J.P.H. Hamers

0

MU Universiteit Maastricht 

Mijnheer de Rector Magnificus,

leden van het College van Bestuur,

leden van de Raad van Bestuur van Zorggroep Meander OZL,

beste collega's, vrienden en familie.

\section{Inleiding}

In oktober 1983 maakte de 18-jarige leerling verpleegkunde, Jan, kennis met de ouderenzorg. Zijn eerste stage aan de HBO-V, een zogenaamde oriëntatiestage, vond plaats in het verpleeghuis. Hij maakte kennis met de afdeling waar hij twee weken zou verblijven; twee weken die hij nooit meer zou vergeten. De visie van de afdeling, beschreven op een paar A4-tjes, vermeldde dat patiënten er een thuis werd geboden en dat zij centraal stonden: patiëntgericht werken was het devies.

De afdeling ademde echter een ziekenhuissfeer, in overwegend urinelucht en met, op het oog, veel bedrijvig personeel in witte uniformen met daarop verschillende insignes of speldjes en zichtbare scharen, en sleutelbossen. Al snel bleek dat je aan de hand van het insigne en omvang van de sleutelbos kon zien waar de verzorgende op de hiërarchische ladder stond.

Op de afdeling trof hij hulpbehoevende ouderen aan, vaak zonder enige vorm van privacy, op 4 en 6-persoonskamers en een dagzaal met bewoners waarvan de meerderheid in de stoel was vastgemaakt met een gordel, een zogenaamde Zweedse band. Jan kreeg al snel zijn eerste twee sleutels; die van het slotje van de Zweedse band en van het personeelstoilet. Regelmatig, vrijwel voortdurend, werd er door bewoners 'broeder' of 'zuster' geroepen. Sommige bewoners riepen dat ze pijn hadden, anderen klaagden onverstaanbaar. Er waren geen activiteiten voor bewoners en familie kwam sporadisch op bezoek.

De dagindeling was eenvoudig en zag er ongeveer zo uit. Tussen 7.0010.30 uur kregen alle bewoners een wasbeurt op bed, werden aangekleed, waarna ze op een zaal werden gezet. Rond 10.30 uur was er bouillon of koffie en een zogenaamde toiletronde. Om 12.00 uur was er een warme maaltijd en rond 13.00 uur werd een deel van de bewoners naar bed gebracht voor een middagdutje dat tot 14.30 uur duurde. Dan weer koffie in een tuitje. Daarna weer de zaal op wachtend op de avondmaaltijd van 
17.00 uur. Niet veel later vertrokken de eerste bewoners weer naar bed; om 20.00 uur was de dagzaal vrijwel verlaten.

Kijkend naar het reilen en zeilen in het verpleeghuis in 1983 viel Jan een aantal zaken op.

In de eerste plaats de concentratie van werkzaamheden in de ochtendspits. Vrijwel al het, voor de verpleging, lichamelijk zware werk was geconcentreerd tussen 7.00 en 10.30 uur. Het leek wel een sport om in een zo kort mogelijk tijdsbestek zoveel mogelijk mensen gewassen en aangekleed in de dagzaal te krijgen. Als verzorgende of verpleegkundige werd je daar in ieder geval op afgerekend. Zo kwam het voor dat Jan zich bij het afdelingshoofd moest melden omdat hij slechts drie in plaats van vier mensen in een uur had verzorgd. En dat scheen zelfs herhaaldelijk te zijn voorgekomen. Een leidinggevende verzorgende had het dubieuze record dat hij meer bewoners kon baden dan sommige collega's bewoners douchten. Het gerucht ging dat hij het badwater niet ververste.

De organisatie van het werk en de rusttijden waren zo strikt georganiseerd dat om precies 10.00 uur de eerste groep verzorgenden koffie ging drinken en de bewoners die zij verzorgden lieten liggen zoals ze lagen. Het was heel gewoon dat een bewoner de hele koffiepauze op de po zat.

In de tweede plaats viel op dat de verpleegafdeling zeer hiërarchisch en naar medisch model was georganiseerd. Het afdelingshoofd stond aan de top, op grote afstand gevolgd door het subhoofd, gevolgd door de verpleegkundige, de ziekenverzorgende, dan een tijd niets, en ten slotte de leerling(zieken)verzorgenden en stagiaires van de HBO-V. Aan Jan werd op de eerste dag al duidelijk gemaakt dat hij op de onderste trede stond.

De organisatiestructuur had een negatieve invloed op de afdelingssfeer. De meeste medewerkers waren bang voor het afdelingshoofd, over een hoofd verplegingsdienst of directeur niet te spreken. Jan leerde al snel dat je niet met lege handen langs het kantoor van het afdelingshoofd moest lopen. Hij werd namelijk weer ontboden, nu met de mededeling dat hij geen gast maar een werker was.

Het takenpakket was als volgt. Het afdelingshoofd zat op kantoor of vergaderde, overlegde met de artsen, maakte iedere maand nieuwe dienstlijsten en verrichte soms een verpleegtechnische handeling zoals het plaatsen van een katether, het geven van een injectie of het ijzen en föhnen van een decubituswond. Het subhoofd verving het hoofd bij diens 
afwezigheid. De eerdergenoemde verpleegtechnische handelingen waren verder voorbehouden aan verpleegkundigen. Het wassen, aankleden, verschonen en 'voeren' van bewoners werd door iedereen gedaan. Vragen van patiënten mochten echter niet beantwoord worden maar moesten eerst aan het afdelingshoofd worden voorgelegd.

Als de werkzaamheden geklaard waren werden plastic zakken gevouwen; verschillende kleuren zakken voor verschillende doeleinden, blauw was voor incontinentiematerialen. Tijdens deze activiteit, die in de dagzaal plaatsvond, werd hulpgeroep van aanwezige bewoners volledig genegeerd en werd ongegeneerd over bewoners gesproken. Toen Jan zich een keer aan de 'zakkenvouw-activiteit' onttrok en een praatje met een bewoner maakte, was de maat vol. Alweer werd hij op het kantoor ontboden.

Drie keer is scheepsrecht: het afdelingshoofd zou richting de opleiding communiceren dat deze leerling niet geschikt was voor het werk in de gezondheidszorg.

Dames en heren, dit fragment is een illustratie van een stukje ouderenzorg ruim twintig jaar geleden. $U$ zult het met mij eens zijn dat dit fragment geen voorbeeld is van goede zorg voor ouderen. Zeker als we die afmeten aan de normen die daarvoor onlangs zijn geformuleerd door Arcares, de Landelijke Organisatie Cliëntenraden en andere partijen in het veld [1]. De stelling 'de ouderenzorg verdient beter' hoef ik voor die periode niet verder toe te lichten.

Dan de stand van zaken in 2005. Wie de afgelopen twee jaren af en toe naar de televisie heeft gekeken of de krant heeft opengeslagen moet het ergste vrezen voor de toestand van de ouderenzorg in Nederland, de verpleeg-en verzorgingshuizen in het bijzonder. Het lijkt er kommer en kwel te zijn; daarvan proberen de media ons in ieder geval te overtuigen. Bewoners schijnen niet meer uit bed te worden gehaald in verpleeghuis $A$ of worden aan hun lot over gelaten in verzorgingshuis B, terwijl instelling $C$ de bewoners niet meer doucht; althans niet dagelijks. En de directeuren in de zorg schijnen meer te verdienen dan onze ministerpresident. De stelling 'de ouderenzorg verdient beter' lijkt dus ook nu in allerlei opzichten op te gaan.

De vraag die zich opdringt is of de huidige intramurale ouderenzorg dan nog slechter is dan twintig jaar geleden. Het antwoord is nee.

Als we nu naar de ouderenzorg kijken dan valt op dat de zorg in de 
meeste instellingen gelukkig niet meer vergelijkbaar is met die van twintig jaar geleden en in grote lijnen is verbeterd, soms zelfs heel goed is, maar uiteindelijk toch beter verdient. Ik zal een aantal voorbeelden van veranderingen voor $u$ opsommen.

\section{Veranderingen in de ouderenzorg}

In de eerste plaats valt op dat de organisatie van de zorg in veel instellingen is aangepast. De organisatie van het verpleeghuis was eind jaren zeventig hiërarchisch en daarmee was het werk van verpleegkundigen en verzorgenden taakgericht. De efficiënte lichamelijke zorgverlening, volgens een vaste structuur, was de voornaamste taak van verpleegkundigen en verzorgenden.

Hoewel nog veel verpleeghuizen te medisch zijn georiënteerd, is de organisatiestructuur in veel instellingen over het algemeen platter, minder hiërarchisch dus, enkele uitzonderingen daargelaten. Tussen de instellingsdirectie en de afdelingen functioneren meestal slechts één of twee leidinggevenden. Afdelingen zijn vaak gesplitst in teams die aangestuurd worden door een teamleider. De teams en de individuele leden van een team zijn meer en meer verantwoordelijk voor de zorg van een of meer bewoners. De autonomie van de teamleden is in veel gevallen toegenomen [10,38]. Deze veranderingen stellen overigens ook andere eisen aan de kwaliteiten van medewerkers. Verzorgenden worden geacht deel te nemen aan multidisciplinaire overlegvormen en onderhouden contacten met de familie van een aan hen toegewezen groep bewoners.

De werksfeer op afdelingen is op veel plaatsen sterk verbeterd $[9,10]$. In veel verpleeg- en verzorgingshuizen is de arbeidstevredenheid onder medewerkers toegenomen $[9,10,39]$ en het ziekteverzuim afgenomen [38]. De toename van arbeidstevredenheid en werkbetrokkenheid is zeer positief omdat een tevreden medewerker een eerste voorwaarde is voor het leveren van goede zorg.

Hoewel men in de jaren zeventig pretendeerde patiëntgerichte zorg te leveren moesten bewoners, toen dus patiënten geheten, zich voegen naar de structuur van de organisatie. Ze hadden vrijwel niets in te brengen. Ook de bejegening van bewoners was aan vastgestelde regels onderhevig. Zo mocht niet worden toegegeven aan de wensen van de patiënt en werd leerlingen geleerd dat een sterke betrokkenheid bij het wel en wee van bewoners niet gewenst was en dat zij afstand moesten bewaren [36]. Daarom was het belangrijk dat men met zuster of broeder 
werd aangesproken en men een wit uniform droeg. Patiënten die veel vroegen waren lastige patiënten en het door de patiënt naar de WC gaan buiten de toiletronde werd gezien als aandacht trekken [36].

Hoewel ik niet kan uitsluiten dat sommige van deze praktijken incidenteel nog kunnen voorkomen is dit gelukkig niet meer de algemene gang van zaken in 2005. Bewoners heten tegenwoordig ook wel cliënten en door het instellen van cliëntenraden is hun inspraakmogelijkheid op het beleid van de instelling verbeterd. De bewoners- of cliëntgerichtheid komt daarmee praktisch al beter uit de verf. Patiëntgerichte zorg heet nu cliëntgerichte of vraaggerichte zorg, waarbij concrete initiatieven worden genomen om daar vorm aan te geven. Een voorbeeld daarvan is de intrede die de bewonersagenda in sommige verpleeghuizen heeft gedaan. De bewonersagenda is een weekagenda voor de individuele bewoner, waarmee wordt getracht meer recht te doen aan een dagindeling die bewoners wensen. De werkzaamheden op de afdelingen worden dan zoveel als mogelijk afgestemd op de behoeften van bewoners. Daarmee wordt langzaam maar zeker, met vallen en opstaan, gewerkt aan de verandering van de dagstructuur.

Opvallend is overigens dat het witte uniform tegenwoordig nog massaal wordt gedragen in verpleeg- en verzorgingshuizen, terwijl daarvoor geen noodzaak is. Op plaatsen waar oudere mensen wonen en leven, moet het witte uniform wat mij betreft verbannen worden.

En dan de effectiviteit van handelen door verpleegkundigen en verzorgenden. Ook daar zijn veranderingen in gang gezet. De voorzichtige introductie van wetenschappelijk onderzoek heeft bijvoorbeeld geleid tot een verbetering van de behandeling van decubitus of doorliggen $[13,17]$. Veel voorkomende handelingen zoals het ijzen en föhnen van decubitus bleken niet zinvol en zijn vervangen door effectieve interventies zoals wisselligging. Ook is er heel recent aandacht in onderzoek naar het voorkomen van pijn bij ouderen met dementie, het beoordelen en verlichten daarvan [11,30]. Op dit momenteel wordt bijvoorbeeld gekeken of bepaalde methoden om pijn te meten kunnen worden toegepast in het dagelijkse werk van verpleegkundigen en verzorgenden, zodat pijn bij ouderen met dementie beter gedetecteerd en behandeld wordt $[42,43]$. Verder zijn er heel recent een aantal belangrijke onderzoeken verricht naar de effecten van belevingsgerichte zorg [31] en naar de effecten van 'snoezelen' [37] bij ouderen met ernstige dementie.

Ten slotte is de inrichting van instellingen duidelijk aan het ver- 
anderen. Steeds meer verpleeghuizen beschikken over twee- of zelfs eenpersoonskamers. Daarnaast is er wat nieuwbouw betreft een trend naar kleinschaligere woonvormen; huizen waar kleine groepen ouderen wonen. Daarmee zijn ook de mogelijkheden voor het behouden van persoonlijke eigendommen beduidend toegenomen, iets wat twintig jaar geleden niet alleen praktisch moeilijk maar vooral niet toegestaan was. Deze ontwikkelingen hebben in ieder geval effect op de privacy van bewoners; die is daarmee beduidend toegenomen. Maar vooral lijken deze kleinschalige woonvormen cliëntgericht werken te bevorderen en positieve effecten te hebben op de kwaliteit van leven van ouderen die erwonen.

\section{Negatieve publiciteit}

Kortom, op verschillende terreinen is vooruitgang geboekt in de zorg voor ouderen.

Heeft u van al deze positieve ontwikkelingen iets in de media vernomen? Ik heb daarover weinig gezien of gelezen. Dat is jammer, want zoals $u$ ziet is en wordt er letterlijk en figuurlijk flink aan de weg getimmerd in de ouderenzorg. Met dit korte overzicht wil ik de negatieve reacties in de media over de ouderenzorg in de afgelopen jaren graag nuanceren. De ouderenzorg verdient beter.

Onlangs vroeg ik een instellingsdirecteur waarom hij niet met positief nieuws naar de krant ging: de Inspectie voor de Gezondheidszorg had de zorg in zijn instelling namelijk als heel goed beoordeeld. Zijn antwoord was dat hij dat ooit had gedaan maar dat nooit meer zou doen. Het persbericht leidde niet tot een eervolle vermelding in een regionaal dagblad, maar tot een negatieve krantenkop en een artikel waarin een familielid, waarmee een conflict was, uit de doeken deed dat de zorg in dat verpleeghuis helemaal niet zo goed was.

Zoals $u$ wellicht weet is de Universiteit Maastricht de beste Universiteit van Nederland; in ieder geval op onderwijsgebied. Anders bent u daarvan nu op de hoogte. Ik kan dat alleen maar onderschrijven en ben trots dat ik aan de UM mag werken. Dat neemt echter niet weg dat er zonder probleem studenten zijn op te trommelen die u graag willen vertellen dat zij de UM helemaal niet zo'n goede onderwijsinstelling vinden. 


\section{Kritische kanttekeningen}

Dames en heren, vandaag wil ik de kritiek op de ouderenzorg in het algemeen, en de verpleeghuizen in het bijzonder, niet bagatelliseren maar benadrukken dat in deze sector de laatste jaren belangwekkende verbeteringen hebben plaatsgevonden. Dat neemt niet weg dat ik vind dat de zorg nog beter kan en moet. Naar mijn mening verdient de ouderenzorg beter.

Er moet in de ouderenzorg namelijk veel meer gebruik worden gemaakt van wetenschappelijke kennis, zowel in het handelen als het opstellen van beleid. Ik zal uitleggen waarom.

Op dit moment richten verpleegkundigen, verzorgenden en andere hulpverleners, maar ook beleidsmakers zich in hun werk te veel op kennisbronnen zoals ervaring, traditie, en autoriteit. Heel veel handelingen in de zorg worden uitgevoerd op basis van persoonlijke ervaringen. Ter illustratie, sommige hulpverleners passen een schapenvacht toe ter voorkoming van decubitus, anderen hebben weer betere ervaringen met het toepassen van een bepaalde crème. Andere handelingen zijn traditioneel van aard. Vooral in de verpleeghuiszorg zijn veel handelingen gebaseerd op traditie. Voorbeelden daarvan zijn de dagelijkse wasbeurt, vaste toiletrondes, het regelmatig opmeten van temperatuur of bloeddruk, en het fixeren of vastbinden van bewoners. Ten slotte is autoriteit een belangrijke kennisbron. Van autoriteiten zoals afdelingshoofden en artsen wordt verwacht dat zij veel kennis in pacht hebben. Veel handelingen zijn gebaseerd op de mening van deze autoriteiten.

Ook beleidsmakers gebruiken veelvuldig hun eigen ervaringen en meningen of die van andere personen bij het opstellen van beleid. Dat geldt ook voor het terugvallen op autoriteit; de mening van een willekeurig samengesteld groepje deskundigen vormt vaak de basis voor ingrijpende beslissingen.

Hoewel ervaring, traditie en autoriteit belangrijke kennisbronnen zijn hebben ze een groot nadeel [28]. Vaak is niet bekend in welke mate en onder welke omstandigheden deze kennis waar is. In de zorgpraktijk van alle dag leidt dit tot meerduidigheid in handelen. Als voorbeelden kunnen wederom decubitus en pijn worden genomen. Het beleid en de handelingen ter voorkoming van decubitus of pijn verschilt niet alleen tussen instellingen maar ook tussen afdelingen in een bepaalde instelling en soms zelfs tussen hulpverleners op een zelfde afdeling. De verklaring is eenvoudig: verschillende ervaringen leiden immers tot andere 
(be)handelingen. En iedere deskundige heeft zijn eigen ervaringen.

Het probleem dat zich nu voordoet is dat we niet weten welke van deze (be)handelingen de meest effectieve is. Welke is de beste preventieve handeling voor decubitus of behandeling tegen pijn bij ouderen met dementie? Welke hupverlener heeft het bij het juiste eind? Hier kan de wetenschappelijke methode uitkomst brengen. We kunnen met behulp van wetenschappelijk onderzoek namelijk op systematische wijze nagaan welke kennis onder welke omstandigheden waar is of niet. En als we dat weten kunnen we richtlijnen formuleren waarmee de beste behandeling beschikbaar komt [8] voor alle ouderen; of die nu in Amsterdam of in Kerkrade in een verpleeghuis wonen of zorg thuis ontvangen. Per individu kan vervolgens worden gekeken of en waarom er van de richtlijn afgeweken zou moet worden.

Dit zelfde geldt voor het opstellen van beleid. Naar mijn mening ontbreekt het in de ouderenzorg aan duidelijke visies op zorg en de organisatie daarvan, vooral op de langere termijn. Het gevolg is dat beleid ten dele gebaseerd wordt op incidenten en daarmee voortdurend aan veranderingen onderhevig is. Dit is de ouderenzorg maar al te vaak het geval. Het beleid naar aanleiding van de wachtlijstproblematiek, de regionale en centrale indicatiestellingen en de kwaliteit van zorg zijn daarvan recente voorbeelden. De waan van de dag lijkt dan te regeren. Moeten we nu samenwerken of concurreren in de zorg? Verschillende bestuurders en beleidsmakers hebben daarover verschillende, niet bewezen, meningen.

Welnu, met wetenschappelijke kennis komen er fundamenten beschikbaar waarop beleid kan worden gemaakt, een visie kan worden ontwikkeld en besluiten veel beter kunnen worden onderbouwd. Kortom meer wetenschap in de ouderenzorg is pure noodzaak.

\section{De ouderenzorg verdient beter $(p<0.001)$}

Dames en heren, de ouderenzorg verdient beter. De ouderenzorg verdient meer wetenschappelijk onderzoek en implementatie van de daarmee verkregen inzichten. Dat symboliseert de $p$-waarde in de titel van mijn rede. Een p-waarde is de uitkomst van een statistische toets waarmee in wetenschappelijk onderzoek de kans wordt aangeduid dat een bevinding op toeval berust. Ik wil echter benadrukken dat de prioriteit van wetenschappelijk onderzoek niet ligt bij het vaststellen dat de ouderenzorg beter verdient, maar juist bij het aandragen van bewezen verbeteringen. 
Kennis verkregen met wetenschappelijke methoden stelt verpleegkundigen, verzorgenden, paramedici en artsen in staat hun werk beter te doen en de kwaliteit van zorg te optimaliseren. Kennis verkregen met wetenschappelijke methoden helpt beleidsmakers een doordachte visie te ontwikkelen en stelt hen in staat om weloverwogen besluiten te nemen die effecten hebben op de middellange en lange termijn.

Voor het geval $u$ nog niet overtuigd mocht zijn zal ik met twee voorbeelden verduidelijken welke belangrijke bijdrage de wetenschap aan de ouderenzorg kan leveren.

Voorbeeld 1: het toepassen van vrijheidsbeperkende maatregelen

Vrijheidsbeperkende maatregelen worden veelvuldig toegepast op psychogeriatrische afdelingen van verpleeg- en verzorgingshuizen. Voorbeelden daarvan zijn het gebruik van bedhekken, Zweedse banden en tafelbladen. De prevalentiecijfers die iets zeggen over het voorkomen van vrijheidsbeperking variëren tussen de 41 en $64 \%[18,19]$. Dat betekent dat ongeveer bij een op de twee bewoners een vrijheidsbeperkende maatregel wordt toegepast. Dit is overigens niet uniek voor Nederland, maar zie je ook in vele andere Europese landen en de VS.

Belangrijke predictoren of voorspellers voor de toepassing van vrijheidsbeperking zijn een slechte mobiliteit van de bewoner, een hoge mate van afhankelijkheid en een verminderd cognitief functioneren [19]. Ik wil graag benadrukken dat er vooralsnog geen aanwijzingen zijn dat een tekort aan personeel samenhangt met het toepassen van vrijheidsbeperking. Wel lijkt er een verband te zijn met het opleidingsniveau van hulpverleners; hoger opgeleiden lijken minder vrijheidsbeperkende maatregelen toe te passen dan lager opgeleiden $[3,6]$. Meer 'handen aan het bed' is dus waarschijnlijk geen oplossing om vrijheidsbeperking te voorkomen; die moet worden gezocht in het scholen van verzorgenden en het aanstellen van meer hoger opgeleide verpleegkundigen.

De belangrijkste reden om vrijheidsbeperking toe te passen is de preventie van vallen. Uit onderzoek komt echter naar voren dat het achterwege laten van vrijheidsbeperkende maatregelen niet leidt tot meer valpartijen of meer letsels $[5,27]$. Uit onderzoek van de Inspectie voor de Gezondheidszorg blijkt dat het toepassen van vrijheidsbeperking zelfs leidt tot (dodelijke) ongelukken [24]. Verder heeft toepassing van vrijheidsbeperking veel negatieve lichamelijke en psychische gevolgen voor de bewoner $[4,12]$. Denk bijvoorbeeld aan incontinentie en depressiviteit. 
Resumerend, wetenschappelijk onderzoek heeft ons inzicht verschaft in de prevalentie van vrijheidsbeperking, de factoren die vrijheidsbeperking voorspellen en de belangrijkste reden om de maatregelen toe te passen. Als we vrijheidsbeperking willen verminderen geven de voorspellende factoren aanknopingspunten voor het ontwikkelen van effectieve interventies.

$\mathrm{Nu}$ zult $\mathrm{u}$ misschien denken: als we weten dat de toepassing van vrijheidsbeperking in de meeste situaties niet adequat is en veel negatieve bijwerkingen heeft, waarom worden die maatregelen dan nog toegepast? We kunnen dan toch beter direct stoppen met het toepassen van vrijheidsbeperkende maatregelen in de zorg. Zo eenvoudig is dat helaas niet. De implementatie van kennis uit wetenschappelijk onderzoek is een vak apart $[22,41]$.

Alle 129.000 hulpverleners in verpleeg- en verzorgingshuizen [2] moeten deze informatie namelijk tot hun beschikking krijgen, maar dienen vooral overtuigd te worden dat hun werkwijze moet worden aangepast. Als je als verzorgende altijd hebt geleerd en gedacht dat fixatie of vastbinden een heupfractuur voorkomt, dan moeten er wel erg goede argumenten zijn om die fixatie nu achterwege te laten. Dat overtuigen geldt voor iedere individuele hulpverlener en voor complete multidisciplinaire teams; als de teamleider, het afdelingshoofd of verpleeghuisarts niet overtuigd is blijven de bestaande maatregelen van toepassing en komt er geen verandering. Zo simpel is dat.

En om het nog complexer te maken, zijn het ook geregeld de familieleden van de bewoner die eisen dat vrijheidsbeperkende maatregelen worden toegepast.

In onze pogingen om hulpverleners te confronteren met de impact van vrijheidsbeperkende maatregelen, hebben we een klein experiment uitgevoerd met medewerkers van verpleeg- en verzorgingshuizen die vrijwillig gedurende 24 uur zijn gefixeerd. Volgens deze medewerkers is het onvoorstelbaar wat het betekent om een etmaal in je vrijheid te worden beperkt. In tegenstelling tot de bewoners was de vrijheidsbeperking voor de medewerkers eindig. Hun ervaringen hebben we samengevat op een DVD en video en deze zijn daarmee beschikbaar voor onder andere collega's en beroepsopleidingen voor verpleegkundigen en verzorgenden.

Verder onderzoek is echter noodzakelijk. Om vrijheidsbeperking te 
reduceren is het bijvoorbeeld belangrijk om meer inzicht te krijgen in de attitude van hulpverleners. Wij hebben met dat doel een vragenlijst ontwikkeld [20]. Een van de vragen die wij stellen luidt: als ik later in een verpleeghuis woon hoop ik dat de verzorgende mij fixeert als zij denkt dat dit het beste voor mij is. Opvallend is dat een grote meerderheid van de verzorgenden die de vragenlijst invult het daar niet mee eens blijkt te zijn. Terwijl zij zelf die beslissing nu wel veelvuldig nemen [21].

Op dit moment voeren wij een gerandomiseerd onderzoek uit naar de effectiviteit van een scholingsprogramma en de inzet van een gespecialiseerde verpleegkundige in de reductie van vrijheidsbeperking [23] Het betreft een zeer complex onderzoek waaraan wordt meegedaan door ruim 400 bewoners met dementie en hulpverleners van 6 verschillende instellingen. De dataverzameling wordt naar verwachting begin 2006 afgerond. Met dit project hopen wij een werkbare en werkzame manier aan te reiken om vrijheidsbeperking te reduceren. Ik sluit echter niet uit dat aanvullende maatregelen, zoals een strengere wetgeving, noodzakelijk zijn.

Voorbeeld 2: vraaggerichte zorg en de zorgbehoefte vanuit cliëntperspectief

In Nederland, maar ook in andere landen met een hoge welvaart, is er de laatste jaren een aanzet gemaakt voor een omkering van een aanbodgestuurde naar een vraaggestuurde zorg. Scherp neergezet komt het neer op het volgende. Bij aanbodgestuurde zorg heb je je als oudere te richten naar het bestaande aanbod aan zorg en voorzieningen. Bij vraaggestuurde of vraaggerichte zorg bepaalt de oudere uiteindelijk hoe het aanbod er uitziet. Het aanbod aan zorg en voorzieningen wordt namelijk ingericht aan de hand van de zorgbehoefte van de ouderen.

De omkering naar een meer vraaggerichte zorg wordt in het algemeen door alle partijen onderschreven en toegejuicht: door patiëntenen cliëntenorganisaties, de aanbieders, verzekeraars enzovoorts. In de praktijk is men druk aan de slag gegaan met het ontwikkelen van allerlei nieuwe voorzieningen, bijvoorbeeld op het gebied van welzijn. Als je oudere mensen een lijstje met die voorzieningen voorlegt en naar hun mening vraagt, lijken ze bijna alles relevant te vinden. De praktijk is echter dat ze van de meeste voorzieningen geen gebruik maken.

Hier openbaart zich een belangrijk probleem: niemand kan zeggen hoe een vraaggericht aanbod eruit moet zien. Dat komt omdat we niet 
weten wat de zorgbehoeften zijn vanuit het perspectief van de cliënt, zowel wat aard als de omvang betreft.

Nu zou je kunnen zeggen dat die omvang toch te berekenen moet zijn. Bijvoorbeeld: kijk naar de huidige zorgvraag en naar de toename van het aantal ouderen en naar de voorspelde toename van het aantal chronisch zieken en ouderen met dementie en bereken dan hoeveel ouderen straks een beroep zullen doen op verpleeghuiszorg. Maar dat is niet zo eenvoudig. In de eerste plaats zijn dat soort voorspellingen niet betrouwbaar, simpelweg omdat ze geen rekening houden met ontwikkelingen die de zorgvraag direct beïnvloeden. De kans is reëel dat het manifest worden van dementie in de toekomst met een aantal jaren vertraagd kan worden [7] of dat diabetes mellitus behandeld kan worden. Dan is de voorspelling dus al niets meer waard. En dan heb ik $u$ nog niet verteld dat mensen met een zelfde ziekte andere behoeften hebben, nog los van het feit dat het ouder worden gepaard gaat met co-morbiditeit; dat wil zeggen dat meerdere ziektes tegelijk voorkomen. Een ziektebeeld als uitgangspunt van voorspellingen is dus zeer discutabel. Bovendien kunnen ook cohorten veranderen; toekomstige generaties ouderen veranderen bijvoorbeeld wat opleidingsniveau en beschikbaarheid van financiële middelen betreft. Maar belangrijker nog is dat voorspellingen niet gebaseerd zijn op de behoeften vanuit het perspectief van ouderen zelf. Anders gezegd, we weten niet wat de aard van de behoeften is, terwijl we juist op zoek zijn naar behoefteramingen die vraaggericht zijn.

Onlangs zijn verschillende onderzoeken verricht om inzicht te krijgen in de behoeften van ouderen vanuit hun perspectief. Daaruit is in de eerste plaats gebleken dat ouderen goed in staat zijn hun behoeften te verduidelijken. Verder komt in onderzoek telkens naar voren dat ouderen zo lang als dat kan zo zelfstandig als mogelijk willen blijven wonen [34]. Maar ook wordt geconcludeerd dat het bijna ondoenlijk lijkt een aanbod aan zorg en voorzieningen te creëren dat op iedere individuele behoefte is afgestemd [33,34]. De sleutel voor een vraaggericht aanbod ligt waarschijnlijk eerder in het ondersteunen van bronnen waarmee mensen aan hun behoeften voldoen. Dat is de kern van een model dat wij hebben ontwikkeld en dat een aanknopingspunt biedt voor het inrichten van een meer vraaggericht zorgaanbod. Een vraaggericht aanbod is niet afgestemd om individuele behoeften, maar op het ondersteunen of vervangen van bronnen waarmee mensen hun behoeften zelf vervullen. Ik zal het model kort toelichten. 
Figuur 1. De relatie tussen behoeften, bronnen en formele hulp.

Cultuur

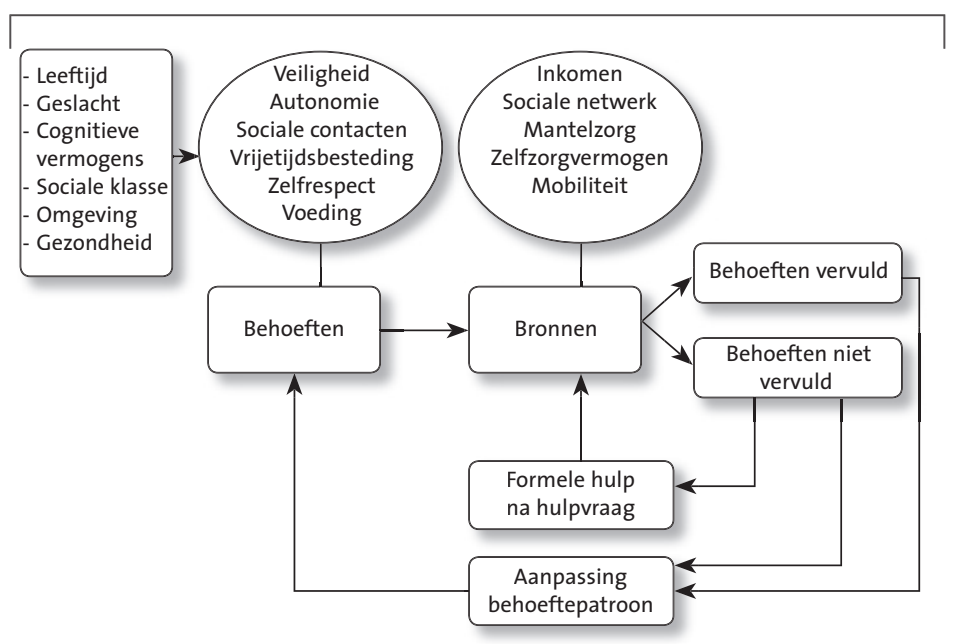

Het model is gebaseerd op de aanname dat mensen universele behoeften hebben variërend van de behoefte aan eten en drinken tot veiligheid en autonomie. Dit patroon aan behoeften, meestal aangegeven als een hiërarchie, wordt beïnvloed door kenmerken van personen zoals leeftijd, geslacht, cognitieve vermogens en gezondheid. Jonge kinderen hebben andere behoeften dan adolescenten, die weer andere behoeften hebben dan ouderen. De behoeften van mensen met een verstandelijke beperking zullen weer anders zijn dan mensen zonder beperking. De tweede aanname is dat mensen hun behoeften vervullen door gebruik te maken van bronnen. Voorbeelden van bronnen zijn het sociale netwerk, het zelfzorgvermogen en de mobiliteit. Als mensen hun behoeften vervullen kan dat leiden tot een aanpassing in het behoeftepatroon. Datzelfde geldt als mensen hun behoeften niet meer kunnen vervullen, als een bron ten dele wegvalt of niet beschikbaar is. De laatste situatie kan echter ook leiden tot een hulpvraag. De derde aanname is dat de formele hulp zich in dat geval primair zou moet richten op het herstel of ondersteuning van de bronnen; bijvoorbeeld het herstellen van de mobiliteit of het ondersteunen van de mantelzorg. Het model volgend ligt hier het aanknopingspunt voor het ontwikkelen van een vraaggericht zorgaanbod. 
Op dit moment doen we twee verschillende onderzoeken in verschillende regio's in Nederland waarmee we de veronderstellingen van het model toetsen. De resultaten van die onderzoeken verwachten we over een jaar te kunnen presenteren. Verder zijn we met Zweedse onderzoekers in overleg om het model te toetsen met de data van een omvangrijke longitudinale Zweedse studie onder ouderen [26]. Gegevens uit die studie suggereren overigens dat de trend van extramuralisering mogelijk leidt tot een beduidende toename in huisarts- en specialistenbezoek door thuiswonende ouderen [29].

\section{Enkele kanttekeningen bij onderzoek}

Met twee voorbeelden heb ik uitgelegd wat de waarde van wetenschappelijk onderzoek voor de ouderenzorg is. Toch wil ik nog een aantal aanvullende opmerkingen maken.

In de eerste plaats hebben de voorbeelden ook een belangrijke beperking van onderzoek aangegeven. Wetenschappelijk onderzoek geeft namelijk niet direct antwoord op alle vragen, maar roept weer nieuwe vragen op. Ter illustratie, als uit onderzoek naar voren komt dat een pijnstiller in 60\% van de situaties werkt, betekent dat ook dat $40 \%$ van de patiënten onvoldoende baat heeft bij het medicament. Dat is belangrijk voor de praktijk. Hulpverleners moeten om deze reden van richtlijnen en protocollen kunnen afwijken en rekening houden met individuele verscheidenheid.

Maar dan moeten er wel eerst wetenschappelijk onderbouwde richtlijnen zijn. Hier is nog een lange weg te gaan. Dit komt enerzijds door het te geringe aantal academisch geschoolde verpleegkundigen, ik kom daar zo meteen op terug. Anderzijds hangt dit samen met het feit dat de effectiviteit van veel interventies in de verpleging en verzorging, zoals scholing of belevingsgerichte zorg, veel minder gecontroleerd is te toetsen dan bij toetsing van farmacologische interventies mogelijk is. Deze beperking is al eerder benadrukt $[15,16,32]$.

Dus, als uit onderzoek blijkt dat een handeling die nu in de praktijk wordt verricht niet effectief is, zoals het vastbinden van ouderen ter voorkoming van vallen, dan weten we nog steeds niet welke handeling wel effectief is. Toch is dat grote winst omdat een nutteloze handeling achterwege kan worden gelaten.

Hieruit volgt dat wetenschappelijk onderzoek tijd kost. En tijd lijken vooral beleidsmakers, bestuurders en politici niet altijd te hebben. Toch is het veel effectiever en doelmatiger een goed onderbouwd besluit te nemen dan voortdurend te moeten terugkomen op ongefundeerde 
besluiten, die door de telkens wisselende actualiteit van de dag onjuist lijken.

In de derde plaats moeten we ervoor waken dat onderzoeksresultaten niet verkeerd worden gebruikt. Dit is bijvoorbeeld het geval als managers op basis van onderzoeksgegevens besluiten dat je als hulpverlener slechts 5 minuten mag besteden aan het aantrekken van een steunkous, of 15 minuten mag doen over een douchebeurt. Daar schiet je als oudere thuis of in het verpleeghuis helemaal niets mee op. Ik hoop dat het voorbeeld over het taakgericht werken in het fragment waarmee ik mijn voordracht begon, dat duidelijk heeft gemaakt.

Ten vierde is het doen van wetenschappelijk onderzoek een vak apart; onderzoekers hebben daarvoor een speciale academische opleiding gevolgd. Aan universiteiten wordt wetenschappelijk onderzoek verricht dat aan strenge eisen moet voldoen. Over het belang van dat soort onderzoek voor de ouderenzorg gaat mijn rede. Het gevaar dreigt echter dat allerlei partijen onderzoeken doen die weinig of niets met wetenschap hebben te maken, maar dat wel, mede door hun quasi-wetenschappelijk taalgebruik lijken te pretenderen. $U$ bent gewaarschuwd.

Ten slotte heb ik al opgemerkt dat implementatie van wetenschappelijke kennis niet van zelf gaat. Het vereist onder andere een bepaald competentie- en expertiseniveau van hulpverleners. Het overwegend lage opleidingsniveau in de ouderenzorg kan daarbij een barrière zijn. Mede daarom is het noodzakelijk dat meer hoger opgeleide hulpverleners werkzaam zijn in de ouderenzorg. Verpleegkundigen met een hogere beroepsopleiding, het zogenaamde niveau 5, bij voorkeur met de nodige levens- en werkervaring. Uitdrukkelijk niet om de baas te spelen over verzorgenden of alleen om verpleegtechnische handelingen te verrichten, maar om als voorbeeld te fungeren en collega's te coachen en een voorloper te zijn in het implementeren van innovaties die de zorg voor ouderen verbeteren. Inhoudelijke leiders dus. De afgestudeerden van de hogere hotelopleiding kunnen dan gewoon naar Golden Tullip.

\section{Onderwijs}

Onderwijs is dus een belangrijke sleutel in het verbeteren van de kwaliteit van ouderenzorg. Dat geldt naast de beroepsopleidingen ook voor de academische opleiding van verpleegkundigen. Als verpleegkundigen wetenschappelijke kennis willen implementeren moeten ze in staat zijn die te selecteren en samen te vatten en zo nodig te vertalen in richtlijnen. Die kennis is ook noodzakelijk voor het opzetten en uitvoeren van 
kleinschalige onderzoeken, zowel op het terrein van het verpleegkundig handelen als op het terrein van het beleid. De Universiteit Maastricht, de Faculteit der Gezondheidswetenschappen in het bijzonder, biedt in ieder geval voldoende mogelijkheden voor academische scholing met de master zorgwetenschappen, de onderzoeksmasters en Europese master verplegingswetenschap. Vanuit de leerstoel zal aan deze master-opleidingen worden bijgedragen. Daarbij wordt in ruime mate aandacht besteed aan mogelijkheden om de effectiviteit van het primaire zorgproces en de organisatie van de zorg te verbeteren. Pijnbestrijding, vrijheidsbeperking en vraaggerichte zorg zijn voorbeelden van thema's waarmee onze studenten in onderwijsmodules aan de slag gaan. Daarbij wordt gestreefd naar een optimale mix tussen praktische en theoretische kennis. Studenten maken kennis met de zorgpraktijk, onder andere door interviews met ouderen en directeuren van zorginstellingen, en praktiseren het vergaren en beoordelen van wetenschappelijke kennis in projectonderwijs. Wij trachten de studenten te enthousiasmeren voor het werk in de ouderenzorg.

De onderwijsactiviteiten vanuit de leerstoel beperken zich niet tot de bachelor- en masterfase, maar betreffen ook de scholing van promovendi. In dat verband wil ik graag melden dat wij in samenwerking met een groot aantal Europese universiteiten, verenigd in de European Academy of Nursing Science (EANS) al een aantal jaren een driejarige zomercursus aanbieden voor promovendi die onderzoek doen op het brede terrein van de verplegingswetenschap. Tijdens de cursus, die ieder jaar aan een andere universiteit in Europa plaatsvindt, wordt onderwijs gegeven door stafleden van de verschillende universiteiten en presenteren promovendi de voortgang van hun onderzoek. 'Research in aging' krijgt ook in deze cursus ruime aandacht.

Volgend jaar juni is de Universiteit Maastricht gastuniversiteit. Ik heb daarover nog goed nieuws. Wij hebben deze maand met EANS namelijk een belangrijke Europese subsidie verworven die de cursus voor promovendi de komende vier jaren mogelijk maakt.

\section{Onderzoek aan de Universiteit Maastricht}

Gezien het belang dat ik hecht aan wetenschappelijk onderzoek in de ouderenzorg, kunt $u$ zich wellicht voorstellen dat ik erg tevreden ben met het instellen van een bijzondere leerstoel Verpleging en Verzorging van Ouderen aan de Universteit Maastricht. Daarmee wordt immers een extra impuls aan onderzoek in de ouderenzorg gegeven. Maar er is meer goed nieuws. 
Binnen het onderzoeksinstituut CAPHRI aan deze universiteit mogen prof. dr. Ruud Kempen, hoogleraar sociale gerontologie, en ik de komende vijf jaren samen vorm geven aan een nieuw onderzoeksprogramma gericht op de ouderenzorg. We hebben dat programma de naam 'innovaties in de zorg voor ouderen' gegeven. Dat programma is gericht op het vaststellen van problemen, het ontwikkelen en toetsen van interventies en het implementeren daarvan. Daartoe werken in het programma diverse promovendi en onderzoekers aan verschillende projecten op het terrein van de ouderenzorg.

Vanuit de leerstoel verpleging en verzorging van ouderen zal het onderzoek zich toespitsen op de thema's effectiviteit van het primaire zorgproces en organisatie van zorg. Binnen het eerste thema doen wij momenteel onderzoek op het terrein van pijn bij ouderen met dementie $[42,43]$, incontinentie [14] en vrijheidsbeperking in de zorg [20,23]. In de toekomst zal dit onderzoek verder worden uitgebouwd. Het uitgangspunt daarbij is niet het aantal onderwerpen binnen dit thema uit te breiden maar nieuw onderzoek te initiëren dat voortbouwt op de resultaten van de lopende projecten.

Binnen het tweede thema, organisatie van zorg, doen wij onderzoek naar de relatie tussen zorgbehoefte, hulpbronnen en (nieuw) zorgaanbod [35] en naar de kwaliteit van zorg in verpleeg- en verzorgingshuizen vanuit het perspectief van cliënten en medewerkers. Aan het einde van dit jaar zullen wij over de kwaliteit van zorg van de verpleeg- en verzorgingshuizen een rapport presenteren. Het is te vroeg om nu in te gaan op de onderzoeksresultaten, maar toch wil ik de inwoners van Limburg, waar dit onderzoek plaatsvindt, al een beetje geruststellen: naar de mening van vertegenwoordigers van bewoners en medewerkers is het geen kommer en kwel in de verpleeg-en verzorgingshuizen. Aangezien het niet denkbeeldig is dat $u$ dat nooit in de krant zult lezen, wilde ik $u$ dat toch alvast melden.

In de toekomst is in ieder geval verder onderzoek naar determinanten voor kwaliteit van zorg en het toetsen en verfijnen van het zorgbehoeftenmodel noodzakelijk. Dit laatste vooral ook in het licht van de ingezette veranderingen met betrekking tot de verregaande extramuralisering van de zorg en de mogelijke toekomstige Wet Maatschappelijke Ondersteuning. Het is namelijk volstrekt onduidelijk wat de precieze consequenties van deze ontwikkelingen zijn voor ouderen. Wetenschappelijk onderzoek is noodzakelijk.

In de uiteindelijke keuzes voor toekomstige onderzoeksprojecten 
maken wij graag gebruik van de expertise van cliënten, overheden, verzekeraars en zorgaanbieders. Wat dat betreft biedt de Provinciale Raad voor de Volksgezondheid (PRV) een mooi platform.

Met een aantal zorgaanbieders hebben we een formeel samenwerkingsverband in het kader van de zogenaamde academisering van de ouderenzorg. In die samenwerking zijn medewerkers vanuit de Universiteit Maastricht gedetacheerd naar instellingen in de ouderenzorg om onderzoek te implementeren en op kleine schaal op te zetten. Jaren geleden zijn we zo gestart met onderzoek in de Zorggroep Meander OZL. De onderzoeksprojecten naar vrijheidsbeperking zijn bijvoorbeeld gestart op initiatief van medewerkers binnen deze zorggroep. Inmiddels is de formele samenwerking uitgebreid met de stichtingen Vivre en Sevagram. In de toekomst zullen mogelijk ook andere instellingen aansluiten. Datzelfde geldt voor de hogeschool Zuyd, de kenniskring 'autonomie en participatie' en de afdeling verpleegkunde in het bijzonder, waarmee wij binnen het nieuwe onderzoeksprogramma graag willen samenwerken.

Zoals $u$ wellicht weet is het doen van onderzoek geen regionale of nationale aangelegenheid. Zeker als we kijken naar de ouderenzorg zien we dat de vergrijzing, en de problemen die deze met zich meebrengt, de landgrenzen overschrijdt. Vanuit Europees perspectief is de vergrijzing in Nederland overigens zo ernstig nog niet [25]. Hoe dan ook, het is belangrijk krachten te bundelen en te leren van situaties in andere landen en gezamenlijk te zoeken naar effectieve maatregelen. Daarom is internationale vergelijking en samenwerking belangrijk.

\section{Onderzoeksprogramma verpleging en verzorging van ouderen}

Jammer genoeg is er niet alleen goed nieuws. Hoewel met het instellen van de bijzondere leerstoel en het onderzoeksprogramma binnen CAPHRI belangrijke voorwaarden zijn geschapen voor onderzoek in de ouderenzorg moeten we vaststellen dat het budget beschikbaar voor onderzoek in de ouderenzorg zeer beperkt is. Hoewel iedereen het belang van onderzoek naar het terugdringen van vrijheidsbeperking, of naar determinanten van zorgkwaliteit belangrijk lijkt te vinden, worden er geen substantiële middelen vrijgemaakt om dat onderzoek mogelijk te maken. Het ministerie van VWS kondigde onlangs aan $€ 130.000 .000$ uit te trekken om farmacologisch onderzoek te stimuleren [40]. Dat is slechts een fractie van het beschikbare budget voor onderzoek in de cure sector. Voor onderzoek in de sector verpleging en verzorging van ouderen, met verreweg de meeste medewerkers in de gezondheidszorg, 
namelijk 261.000, die in verpleeghuizen, verzorgingshuizen en thuiszorg zorgen voor een van de kwetsbaarste, en in omvang grootste, groepen in onze samenleving, is nog geen $10 \%$ van het genoemde bedrag beschikbaar. De ouderenzorg verdient beter!

Een langlopend programma voor onderzoek in en van de verpleging en verzorging van ouderen is dringend noodzakelijk. Het ministerie, de staatsecretaris in het bijzonder, is aan zet.

Dames en heren, aan het eind gekomen van mijn rede, rest mij $u$ nog te vertellen hoe het met leerling verpleegkundige Jan is afgelopen, de hoofdpersoon in de illustratie aan het begin van mijn rede. Ik kan $u$ geruststellen: met hem is het nog goed gekomen. Hij werd toch geschikt gevonden voor het werk in de gezondheidszorg, en werkte later als verpleegkundige in de ouderenzorg. Tegenwoordig werkt hij aan de beste universiteit van Nederland. 


\section{Dankwoord}

Graag wil ik mijn rede besluiten met een dankwoord.

Het College van Bestuur van de Universiteit Maastricht, het bestuur van de Faculteit der Gezondheidswetenschappen en de Raad van Bestuur van de Zorggroep Meander OZL dank ik voor het in mij gestelde vertrouwen. Twee personen wil ik daarbij met name noemen, te weten prof. dr. Frits van Merode, decaan van de Faculteit der Gezondheidswetenschappen en drs. Roger Ruijters, lid van de Raad van Bestuur van Zorggroep Meander. Ik zal mijn uiterste best doen de verwachtingen waar te maken.

De directeur van onderzoeksinstituut CAPHRI, prof. dr. Guy Widdershoven, dank ik voor de mogelijkheid een nieuw onderzoeksprogramma op het terrein van de ouderenzorg te starten. Ik verwacht veel van de resultaten van de samenwerking op dit terrein met prof. dr. Ruud Kempen.

De bakermat van de academisering van de verpleging in Nederland ligt in Maastricht. Ik heb daar in mijn opleiding veel geleerd van onder andere prof. dr. Huda Huijer Abu-Saad, prof. dr. Hans Philipsen, dr. Ruud Halfens en prof. dr. Marcel van den Hout. Met de instelling van een bijzondere leerstoel op een specifiek terrein, de Verpleging en Verzorging van Ouderen, blijkt de Universiteit Maastricht wederom een voorloper te zijn. Hopelijk doet goed voorbeeld goed volgen. Vanuit Maastricht zullen prof. dr. Rianne de Wit en ik in ieder geval hard aan de weg blijven timmeren. Wat dat betreft kijk ik positief naar de toekomst.

Bij de Universiteit Maastricht dank ik prof. dr. Frans van Wijmen en alle collega's bij de cluster zorgwetenschappen. De medewerkers van de sectie verplegingswetenschap dank ik in het bijzonder. Bij deze sectie werk ik al heel wat jaren met plezier en is een stevig fundament gelegd voor de uitbouw van het onderzoek in de ouderenzorg. Bij mijn promotie, precies tien jaar geleden, zongen mijn toenmalige collega's 'de meeste dromen zijn bedrog, niet voor Jan Hamers, professor wordt hij toch'. Hoewel dat toen helemaal niet aan de orde was, hadden zij, naar nu blijkt, een vooruitziende blik.

Nadrukkelijk gaat mijn dank uit naar de promovendi en onderzoekers die ik op dit moment mag begeleiden. Zij zijn het die de onderzoeksprotocollen aanscherpen en de onderzoeken enthousiast en accuraat uitvoeren.

Een speciaal woord van dank naar al mijn collega's in de zogenaamde niet-wetenschappelijke functies. Zij zorgen er mede voor dat ik mijn 
werk goed kan doen. Martha Theng en Julie Rosier noem ik bij naam. Dank voor het bewaken van mijn agenda en het mede-organiseren van mijn werk, maar ook voor de herinneringen aan andere belangrijke activiteiten en gelegenheden.

Bij de Zorggroep Meander dank ik de leden van de werkgroep zorgonderzoek die al verschillende onderzoeksprojecten mede tot een succes hebben gemaakt. Drs. Math Gulpers noem ik met naam omdat hij sinds de start in 1998 actief deel uitmaakt van de werkgroep en Marjo Schlangen omdat zij al die tijd zorgt voor de nodige ondersteuning.

Mijn werkzaamheden voordeProvinciale Raad voor deVolksgezondheid hebben ongetwijfeld bijgedragen aan het fundament voor onderzoek in de ouderenzorg. Daarvoor wil ik de leden van de Raad onder aanvoering van prof. dr. Wim Groot, en de gedeputeerden Martin Eurlings en Odile Wolfs, bedanken. Maar vooral een woord van dank aan de medewerkers van de afdeling zorg van de provincie Limburg, waarmee ik regelmatig samenwerk. Lia Selen en drs. Paul Ernst wil ik met name noemen.

Met prof. dr. Jan de Jonge, recent benoemd aan de Technische Universiteit van Eindhoven, heb ik de afgelopen jaren veel samengewerkt op het snijpunt van de organisatiepsychologie en de verplegingswetenschap. Ik hoop dat er ook in de toekomst voldoende aanleiding zal om gezamenlijk onderzoek te verrichten.

Ten slotte ben ik dank verschuldigd aan een aantal van mijn bronnen, om de terminologie van het eerder besproken model te gebruiken. Aan mijn familie en vrienden, mijn schoonouders, mijn zus Marita, Bert en Benthe en mijn vader. En aan mijn moeder, voor haar lessen in creativiteit en bescheidenheid. Aan haar draag ik deze rede op.

Ten slotte natuurlijk Stella, die als geen ander weet dat samenleven met Jan Hamers soms moeilijker is dan het lijkt: bedankt. En mijn liefste Maud, die papa wilde verbieden haar nog langer dagelijks naar school te brengen, omdat ze dacht dat hij daarbij voortaan deze jurk zou dragen. Zij heeft haar beeld van een professor, een oude man met een klein brilletje die geheime drankjes mengt, snel bijgesteld.

Dames en heren, mogelijk heeft ook $u$ vanmiddag uw beeld over deze professor bijgesteld. Ik hoop in ieder geval dat $u$ een goede indruk heeft gekregen van mijn huidige en toekomstige werkzaamheden en de speerpunten binnen de leerstoel. Ik dank $u$ allen voor uw belangstelling en aandacht.

Ik heb gezegd. 


\section{Referenties}

1. Arcares, AVVV, LOC, NVVA, Sting (2005). Op weg naar normen voor verantwoorde zorg. Utrecht: Arcares

2. AVVV (2005). Jaarboek 2004-2005. Utrecht: AVVV

3. Bourbonniere M, Strumpf NE, Evans LK, Maislin G (2003). Organizational characteristics and restraint use for hospitalized nursing home residents. JAGS 51:1079-1084

4. Capezuti E (2004). Minimizing the use of restrictive devices in dementia patients at risk for falling. Nurs Clin N Am 39:625-647

5. Capezuti E, Strumpf NE, Evans LK, Grisso JA, Maislin G (1998). The relationship between physical restraint removal and falls and injuries among nursing home residents. J Gerontol 53A:M47-M52

6. Castle NG (2002). Nursing homes with persistent deficiency citations for physical restraint use. Med Care 40:868-878

7. Cummings JL (2004). Alzheimers's disease. N Engl J Med 351:56-67

8. De Haan RJ (1997). Klinische epidemiologie in de verpleegkunde: revolte of renaissance? Utrecht: Bunge (oratie)

9. De Jonge J, Van Vegchel N, Hamers JPH (2002). Onderzoek werk en werkbeleving Zorggroep Meander, rapport panelonderzoek. Utrecht: Universiteit Utrecht

10. De Jonge J, Van Vegchel N, Hamers JPH (2003). Onderzoek werk en werkbeleving Sector ouderenzorg GOZL, rapport panelonderzoek. Utrecht: Universiteit Utrecht

11. De Wit R, Boerlage A, Stronks DL, Baar FPM (2004). Vóórkomen van pijn bij bewoners in verpleeg- en verzorgingshuizen. Pijn Info 1(oktober):73-82

12. Dielis-van Houts AM, Lendemeijer BHGM, Hamers JPH (2003). Op zoek naar de balans tussen veiligheid, vrijheid en vrijheidsbeperking. In: I Jongerden, Y Heijnen-Kaales (Eds.). State of the art studie verpleging en verzorging, Elsevier, Maarssen

13. Duimel-Peeters IGP, Halfens RJG, Berger MPF, Snoeckx LHEH (2005). The effects of massage as a method to prevent pressure ulcers: a review of the literature. Ostomy Wound Manag 51:70-80

14. Du Moulin MFMT, Hamers JPH, Paulus A, Berendsen C, Halfens R (2005). The role of the nurse in community continence care: a systematic review. Int J Nurs Stud 42:479-492

15. Frederiks CMA (2000). Tot hiertoe. Nijmegen:Katholieke Universiteit Nijmegen (afscheidsrede)

16. Grypdonck M (2005). Tussen verpleegkunde en verplegingswetenschap. Utrecht: UMCU (afscheidsrede)

17. Halfens RJG, Bours GJJW, Bronner CM (2001). The impact of assessing the prevalence of pressure ulcers on the willingness of health care institutions to plan and implement activities to reduce the prevalence. J Adv Nurs 36: 617625

18. Hamers JPH, Gulpers MJM, Strik W (2004). Use of physical restraints with cognitively impaired nursing home residents. J Adv Nurs 45:246-251 
19. Hamers JPH, Huizing AR (2005a). Why do we use physical restraints in the elderly? Z Geront Geriatr 38: 19-25

20. Hamers JPH, Huizing AR (2005b). The use of physical restraints in elderly people: nurses' attitudes. 18th congress of the international association of gerontology. Rio de Janeiro, Brazil, June 26-30

21. Hamers JPH, Van Wijmen F (2003). Vrijheidsbeperking in de zorg, een verpleegkundige beslissing. TVZ 113 (7):30-33

22. Huijer Abu-Saad H (2003). Partnerships in de zorg in Nederland. Verpleegkunde 18:114-122 (afscheidsrede)

23. Huizing AR, Hamers JPH, Berger MPF, Gulpers MJM, Smeets I, Lendemeijer B, Widdershoven GAM (2003). Het verminderen van fixaties bij psychogeriatrische verpleeghuisbewoners. Verpleegkunde 18:244-245

24. Inspectie voor de Gezondheidszorg (2000).Veiligheidsrisico's bij het gebruik van bedden, bedhekken en fixatiemateriaal in verpleeghuizen. Den Haag: IGZ

25. Kempen GIJM (2003). Een beetje mens vergrijst niet. Maastricht: Universiteit Maastricht (oratie)

26. Lagergren M, Von Straus E, Elmstahi S, Rahm Hallberg I (2005). SNAC - the Swedish National Study of Aging Care. 18th congress of the international association of gerontology. Rio de Janeiro, Brazil, June 26-30

27. Neufeld RR, Libow LS, Foley WJ, Dunbar JM, Cohen C, Breuer, B (1999). Restraint reduction reduces serious injuries among nursing home residents. JAGS 47:1202-1207

28. Polit DF, Hungler BP (1995). Nursing research, principles and methods. Philadelphia: Lippincott

29. Rahm Hallberg I (2005). Good aging in Skane, a substudy of SNAC; the care and social service part.18th congress of the international association of gerontology. Rio de Janeiro, Brazil, June 26-30

30. Scherder E, Oosterman J, Swaab D et al. (2005). Recent developments in pain in dementia. Brit Med J 330:461-464

31. Schrijnemaekers V, Van Rossum E, Candel M, Frederiks C, Derix M, Sielhorst $H$, Van den Brandt P (2002). Effects of emotion-oriented care on elderly people with cognitive impairment and behavioral problems. Int J Geriatr Psychiatry 17:926-937

32. Van Achterberg $T$ (2002). Where is my nurse? Over onderzoek en oorbare zorg Nijmegen: Katholieke Universiteit Nijmegen (oratie)

33. Van Bilsen PMA, Hamers JPH, Groot W, Spreeuwenberg C (2002). Welke zorg vragen ouderen? Een inventarisatie. Maastricht: UPM

34. Van Bilsen PMA, Hamers JPH, Groot W, Spreeuwenberg C (2003). Een andere kijk op wachtlijstproblematiek. De behoefte van ouderen aan verzorgingshuiszorg. Maastricht: UPM

35. Van Bilsen PMA, Hamers JPH, Groot W, Spreeuwenberg C (2005). Consumers' and Family Caregivers' Perspectives on Community-Based Homecare and Welfare Services: An Acceptable Alternative for Residential Care? 58th Annual Meeting of The Gerontological Society of America. Orlanda, USA, November 18-22 
36. Van den Heuvel WJA (1977). Het verpleegtehuis. Leven van huis uit. Nijmegen: Dekker \& van de Vegt

37. Van der Weert JCM, Van Dulmen AM, Spreeuwenberg PMM, Ribbe MW, Bensing JM (2005). Behavioral and mood effects of snoezelen integrated into 24-hour dementia care. JAGS 53:24-33

38. Van der Windt W, Calsbeek H, Talma H, Hingstman L (2003). Feiten over verpleegkundige en verzorgende beroepen. Maarssen: Elsevier

39. Van Vegchel N, De Jonge J, Meijer T, Hamers JPH (2001). Different effort constructs and effort-reward imbalance: effects on employee well-being in ancillary health care workers. J Adv Nurs 34:128-136

40.VWS (2005). Minister wil investeren in onderzoek (nieuwsbericht 19-8-2005). Den Haag: VWS

41. Wensink M, Grol R (2005). Determinants of effective change. In: R Grol, M Wensing, $M$ Eccles (Eds.). Improving patient care. The implementation of change in clinical practice. Edinburgh: Elsevier

42. Zwakhalen SMG, Hamers JPH, Berger MPF, Peijnenburg R (2005). Nurses' attitudes on pain in elderly nursing home residents. 11th World Congress on Pain, Sydney, Australia, August 21-26

43. Zwakhalen SMG, Hamers JPH, Huijer Abu-Saad H, Berger MPF (submitted for publication). Pain in elderly people with severe dementia: a systematic review of behavioural assessment tools. 
